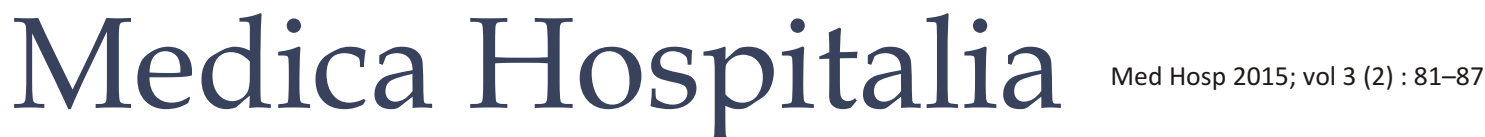

Original Article

\section{Perbandingan Efektivitas Klinik Larutan Gentian Violet dengan Mikonazol Krim pada Terapi Otomikosis}

\author{
Enny Puji Astuti, Pujo Widodo, Dian Ayu Ruspita, Muyassaroh \\ Departemen IKTHT-KL Fakultas Kedokteran Universitas Diponegoro/SMF KTHT-KL RSUP Dr. Kariadi Semarang
}

\begin{abstract}
Abstrak
Latar belakang : Kejadian otomikosis sekitar 9-40\% dari seluruh kasus otitis eksterna. Penatalaksanaan otomikosis meliputi ear toilet secara berkala dan medikamentosa dengan antimikotik yang dapat diberikan secara topikal atau dikombinasi secara sistemik. Antimikotik topikal dapat berupa larutan maupun krim. Penelitian ini bertujuan untuk membandingkan efektivitas klinik larutan gentian violet $1 \%$ dengan mikonazol krim $2 \%$ pada terapi otomikosis.

Metode : Penelitian quasy eksperimental, dengan desain pre dan post test. Subjek adalah penderita otomikosis. Penegakan diagnosis otomikosis berdasarkan anamnesis, pemeriksaan fisik dan pemeriksaan pengecatan jamur dari Swab CAE. Subjek terdiri dari 2 kelompok terapi yaitu kelompok gentian violet (GV) dan mikonazol krim, dievaluasi keluhan (gatal, discad, nyeri, kurang dengar dan tinitus) dan tanda klinik (discad, edem dan debris CAE) pada hari ke-3,7,10 dan 14 . Subjek diberi terapi lanjutan berupa aplikasi ulang GV atau mikonazol, sebelumnya dilakukan ear toilet untuk evaluasi. Pengecatan jamur ulang pada hari ke-7 dan 14 . Uji statistik dilakukan menggunakan uji Chi square dan dan Manova. Hasil : Didapatkan 55 subjek otomikosis, 28 subjek kelompok GV dan 27 subjek kelompok mikonazol krim. Jenis kelamin laki-laki ada 25 subjek $(45,4 \%)$ dan perempuan 30 subjek (54,6\%). Kelompok usia terbanyak 41-50 tahun, sebanyak 19 subjek $(34,60 \%)$. Hasil analisis pasca terapi menunjukkan perbedaan perbaikan keluhan gatal $(p=0,009)$, discad $(p=0,005)$, nyeri $(p=0,012)$, kurang dengar $(p=0,015)$, tinnitus $(p=0,009)$. Terdapat perbedaan tanda klinik: edem CAE $(p=0,009)$, discad $(p=0,011)$, debris $(p=0,008)$. Tidak terdapat perbedaan perubahan hasil pengecatan jamur pada hari ke-7 $(p=0,422)$, dan hari ke-14 $(p=1,000)$.

Simpulan : Terapi larutan gentian violet lebih memberikan perbaikan keluhan dan tanda klinik dibanding terapi mikonazol, tetapi tidak berbeda dalam perubahan pengecatan jamur pasca terapi.
\end{abstract}

Kata Kunci : Otomikosis, efektivitas terapi, gentian violet dan mikonazol

\section{The comparison of gentian violet liquid solution and miconazol cream for otomikosis treatment}

\section{Abstract}

Background: Otomikosis incidence of approximately 9-40\% of all cases of otitis externa. Management otomikosis include ear toilet regularly and Medical with antimycotics that can be administered topically or systemically combined. Topical antimycotics can be either a solution or cream. The objectives of this study was to compared the clinical effectiveness of the solution gentian violet $1 \%$ to $2 \%$ miconazole cream in the treatment of otomikosis.

Methods : Quasy experimental research, with pre and post test design. Subjects were patients otomikosis. Otomikosis diagnosis based on history, physical examination and fungal staining of Swab CAE. Subjects consisted of two treatment groups ie groups Gentian violet (GV) and miconazole cream, then evaluated the symptom (itching, discaj, pain, hearing loss and tinitus) and clinical signs (discad, edema and debris CAE) on days 3,7,10 and 14. Subjects were given further treatment in the form of re-GV application or miconazole, previously performed ear toilet for evaluation. Refungal painting on day 7 th and 14th. Statistical testing was performed using Chi square test and Manova test.

Results : Fifty five subjects otomycosis, 28 in the GV group and 27 in groups of miconazole cream. Male gender there are 25 subjects $(45,4 \%)$ and 30 female subjects (54.6\%). The largest age group is 41-50 years, a total of 19 subjects (34.6\%). Results of post-therapy data analysis shows that there are differences improvement symptom in itching $(p=0.009)$, discharge $(p=0.005)$, pain $(p=0.012)$, hearing loss $(p=0.015)$, tinitus $(p=0.019)$. There are differences in clinical signs: CAE edema $(p=0.009)$, discharge $(p=0.011)$, debris $(p=0.008)$. There is no difference on changes of fungal staining at day $7(p=0.422)$ and day $14 \quad(p=1.000)$. Conclusion : Gentian violet solution provides better than miconazol cream in improvement of symptom and clinical sign, but did not differ in fungal staining in the post-treatment.

Keywords : Otomycosis, efectivity of therapy, genitian violet, miconazol 


\section{PENDAHULUAN}

Otomikosis adalah suatu peradangan pada liang telinga luar (CAE) yang disebabkan oleh infeksi jamur., ${ }^{1,2}$ Kejadian otomikosis sekitar 9-40\% dari seluruh kasus otitis eksterna. ${ }^{3}$ Infeksi otomikosis lebih sering terjadi pada usia remaja dan dewasa muda, pada golongan sosioekonomi rendah yang lingkungannya kurang sehat. ${ }^{3,4}$

Otomikosis dapat terjadi kronik, sub akut maupun maupun akut. ${ }^{4,5}$ Spesies jamur yang sering menginfeksi adalah aspergillus sp (80\%), diikuti candida sp. Jamur menginfiltrasi secara lokal di epitel liang telinga luar (CAE) pada daerah yang rentan atau terdapat lokus minoris kemudian akan menimbulkan reaksi peradangan pada kulit di CAE. ${ }^{2,3}$

Penegakan diagnosis otomikosis berdasarkan gejala klinik dan pemeriksaan penunjang yaitu pengecatan jamur (fungal staining) $\cdot^{1,2}$ Hasil pengecatan tampakjamur $p$ seudohyfa dan/ atau hifa yang merupakan bentukan jamur yang telah menginfiltrasi jaringan sekitarnya. ${ }^{6}$ Gejala klinik otomikosis sering tidak spesifik, seperti: pruritus (rasa gatal) pada liang telinga, otalgia (nyeri telinga), otore serous (discharge telinga), tinitus dan kurang pendengaran., ${ }^{2,6}$

Penatalaksanaan otomikosis meliputi ear toilet secara berkala dan antimikotik yang dapat diberikan secara topikal atau dikombinasi secara sistemik. 7,8 Antimikotik topikal dapat berupa larutan maupun krim. Anti mikotik larutan bersifat nonspesifik dan broadspectrum, misalnya: larutan gentian violet (GV)
1-2\%, larutan asam asetat 2-5\% dalam alkohol (tetes telinga), asam asetat nonakueus $2 \%$, m-kresil asetat $2 \%$, larutan timol 2\%. Antimikotik spesifik topikal bentuk krim misalnya: mikonazol 2\%, ketokonazol $2 \%$, klotrimazol 2\%, flukonazol 2\%. Anti mikotik diberikan minimal 2 minggu, dapat dilanjutkan 2 minggu setelah gejala klinik menghilang. ${ }^{9,10}$

Tujuan penelitian ini untuk membandingkan efektivitas klinik larutan gentian violet 1\% dengan Mikonazol krim 2\% pada terapi otomikosis.

\section{METODE}

Penelitian ini menggunakan pasien sebagai subjek penelitian. Sampel yang telah ditentukan sebanyak 27 setiap kelompok. Sampel penelitian ini adalah semua subjek dengan keluhan dan tanda klinik otomikosis. Penelitian ini bersifat intervensi pre-post tes design, quasy eksperimental. Terapi GV 1\% dan mikonazol 2\% sebagai variabel bebas sedangkan perubahan klinik (keluhan, tanda klinik dan pengecatan jamur) sebagai variabel tergantung. Penelitian dilakukan di klinik otologi THT RS Kariadi selama bulan Maret-Mei 2015. Kriteria inklusi: hasil pengecatan jamur CAE: hifa/ pseudohifa $(+)$. Kriteria eksklusi: Pasien dengan membran timpani perforasi, dengan defisiensi imun: DM, HIV. Sering melakukan ativitas di air : perenang, penyelam. Kriteria drop out: Pasien yang mengalami perburukan gejala selama terapi, pasien yang alergi terhadap lar. gentian violet atau mikonazol krim, pasien tidak kembali kontrol. Subjek diambil secara concecutive sampling.

\section{TABEL 1}

\section{Karakteristik subjek penelitian dan uji normalitas data}

\section{Variabel}

Mikonazol

$(\%)$

$(n=27)$
$5(18,5)$

$6(22,2)$

$3(11,1)$

$9(33,3)$

$2(7,40)$

$2(7,40)$
Kelompok

Gentian violet
$(\%)$
$(n=28)$

Total

$(n=55)$

Kelompok usia (tahun)

$\begin{array}{ll}10-20 & 5(18,5) \\ 21-30 & 6(22,2) \\ 31-40 & 3(11,1) \\ 41-50 & 9(33,3) \\ 51-60 & 2(7,40) \\ 61-70 & 2(7,40)\end{array}$

$6(21,4)$

$5(17,8)$

$2(7,14)$

$10(35,7)$

$3(10,7)$

$2(7,14)$

$15(53,5)$

$13(46,5)$
$11(20,0)$

$11(20,0)$

$5(9,09)$

$19(34,6)$

$5(9,09)$

$4(7,27)$

$25(45,4)$

0,297 *

Laki-laki

$10(37,1)$

$17(62,9)$

Perempuan

$30(54,6)$

Ket: * Uji Saphiro Wilk, $p<0,05$ 
Subjek penelitian dikelompokkan menjadi 2 kelompok terapi: kelompok gentian violet (GV) dan kelompok mikonazol. Evaluasi keluhan dan tanda klinik dan terapi ulang dilakukan pada hari ke-3, 7, 10 dan 14. Keluhan yang dievaluasi: CAE gatal, keluar discad, nyeri, kurang dengar dan tinnitus. Keluhan dinilai dengan skor VAS, dianggap membaik jika terdapat penurunan skor VAS $>2$. Tanda klinik yang dievaluasi: Discad CAE, edem dan debris. Saat pasien kontrol, dilakukan ear toilet dan aplikasi ulang terapi oleh pemeriksa. Evaluasi pengecatan jamur dilakukan pada hari ke-7 dan ke-14.

Uji statistik dengan uji Chi Square (X2) dan uji Manova untuk analisis multivariat. Kemaknaan ditentukan berdasarkan nilai $p<0,05$ dengan interval kepercayaan 95\%. Penelitian disetujui Komisi Etik Penelitian Kesehatan (KEPK) FK Undip dan RSUP Dr. KariadiSemarang.

\section{HASIL}

Subjek penelitian sebanyak 55 , terdiri dari 28 subjek pada kelompok terapi GV, 27 subjek pada kelompok terapi mikonazol krim.

Kelompok terapi GV 28 subjek, laki-laki ada 15 subjek, perempuan ada 13 subjek. Rentang usia kelompok terapi gentian violet antara 10-69 tahun. Distribusi usia homogen, Rerata usia 34,30 tahun, median usia 30,0 tahun. Frekuensi terbanyak pada kelompok usia 41-50 tahun sebanyak 10 orang. Otomikosis unilateral terjadi pada semua subjek. Kelompok mikonazol 27 subjek, rentang usia antara 11-70 tahun. Rerata usia 34,67 tahun, median usia 37,50 tahun. Frekuensi terbanyak pada kelompok usia 41-50 tahun sebanyak 9 .

Pada hari ke-3, ke-7 dan ke-10 kelompok GV mengalami perbaikan keluhan gatal lebih baik dibanding kelompok mikonazol (Nilai $p<0,05$ terdapat perbedaan bermakna). Pada hari ke-14 perbaikan keluhan gatal tidak berbeda antara kedua kelompok $(p=1,000)$. Terdapat perbedaan bermakna keluhan gatal pada kelompok gentian violet dibanding kelompok mikonazol.

Tabel 3 pada hari ke-3 dan ke-7 pasca terapi kelompok gentian violet mengalami perbaikan keluhan keluar discad CAE yang lebih baik daripada kelompok mikonazol. Terdapat perbedaan bermakna $(p<0,05)$. Pada hari ke-10 $(p=0,112)$, hari ke-14 $\quad(p=0,492)$ ini menunjukkan perbaikan keluhan keluar discad tidak berbeda antara 2 kelompok pada hari ke-10 dan ke-14. Terdapat perbedaan perbaikan keluhan discad secara bermakna pada kelompok GV dibanding kelompok mikonazol.

Pada hari ke-3 pasca terapi tidak terdapat perbedaan perbaikan keluhan nyeri pada kedua kelompok $(p=0,222)$. Hari ke-7 terdapat perbedaan perbaikan keluhan nyeri pada kedua kelompok $(p=0,012)$. Pada hari ke-10 dan 14 juga tidak terdapat

\begin{tabular}{|lccc|}
\hline $\begin{array}{l}\text { TABELL. 2 } \\
\text { Perbedaan perbaikan keluhan gatal } \\
\text { kedua kelompok }\end{array}$ \\
Gatal & \multicolumn{3}{c|}{ Kelompok } \\
& $\begin{array}{c}\text { Mikonasol } \\
\boldsymbol{n = 2 7 ( \% )}\end{array}$ & $\begin{array}{c}\text { Gentian violet } \\
\boldsymbol{n = 2 8}(\%)\end{array}$ & $\boldsymbol{p}$ \\
\hline Hari 3 & $0(0)$ & $20(71,4)$ & $0,009^{*}$ \\
Hari 7 & $11(40,7)$ & $27(96,4)$ & $0,011^{*}$ \\
Hari 10 & $24(80,0)$ & $28(100)$ & $0,034^{*}$ \\
Hari 14 & $27(100)$ & $28(100)$ & 1,000 \\
\hline
\end{tabular}

Ket: *: Chi-Square, $p<0,05, \mathrm{Cl} 95 \%$

\begin{tabular}{|lccc|}
\hline $\begin{array}{l}\text { TABEL } 3 \\
\text { Perbedaan perbaikan keluhan discad CAE } \\
\text { kedua kelompok }\end{array}$ \\
$\begin{array}{l}\text { Discad } \\
\text { CAE }\end{array}$ & $\begin{array}{c}\text { Melompok } \\
\boldsymbol{n = 2 7}(\%)\end{array}$ & $\begin{array}{c}\text { Gentian violet } \\
\boldsymbol{n = 2 8}(\%)\end{array}$ & $\boldsymbol{p}$ \\
\hline Hari 3 & $1(3,57)$ & $22(78,5)$ & $0,005^{*}$ \\
Hari 7 & $2(7.40)$ & $26(92,7)$ & $0,009^{*}$ \\
Hari 10 & $26(96,2)$ & $28(100)$ & 0,112 \\
Hari 14 & $27(100)$ & $28(100)$ & 0,492 \\
\hline
\end{tabular}

Ket: *: Chi-Square, $p<0,05, \mathrm{Cl} 95 \%$

$\begin{aligned} & \text { TABEL } 4 \\
& \text { Perbedaan perbaikan keluhan nyeri CAE } \\
& \text { kedua kelompok }\end{aligned}$
\begin{tabular}{lccc} 
Nyeri CAE & \multicolumn{3}{c}{ Kelompok } \\
& $\begin{array}{l}\text { Mikonasol } \\
\boldsymbol{n = 2 7}(\%)\end{array}$ & $\begin{array}{c}\text { Gentian violet } \\
\boldsymbol{n = 2 8}(\%)\end{array}$ & $\boldsymbol{p}$ \\
\hline Hari 3 & $5(59,7)$ & $9(32,1)$ & 0,222 \\
Hari 7 & $14(51,8)$ & $27(96,4)$ & $0,012^{*}$ \\
Hari 10 & $24(88,8)$ & $28(100)$ & 0,103 \\
Hari 14 & $26(96,2)$ & $28(100)$ & 0,112 \\
\hline
\end{tabular}

Ket: *: Chi-Square, $p<0,05, \mathrm{Cl} 95 \%$

perbedaan bermakna antara kedua kelompok $(p=0,103$ dan $p=0,112)$. Terdapat perbedaan bermakna pada perbaikan keluhan nyeri kelompok GV dibanding kelompok mikonazol.

Pada hari ke-3, ke-7 dan ke-10 pasca terapi terdapat perbedaan bermakna pada perbaikan keluhan kurang dengar pada kedua kelompok $(p<0.05)$. 


\begin{tabular}{|lccc|}
\hline $\begin{array}{l}\text { TABEL } 5 \\
\text { Perbedaan perbaikan keluhan kurang dengar } \\
\text { kedua kelompok }\end{array}$ \\
$\begin{array}{l}\text { Kurang } \\
\text { dengar }\end{array}$ & $\begin{array}{c}\text { Melompok } \\
\boldsymbol{n = 2 7}(\%)\end{array}$ & $\begin{array}{c}\text { Gentian violet } \\
\boldsymbol{n = 2 8}(\%)\end{array}$ & $\boldsymbol{p}$ \\
\hline Hari 3 & $0(0)$ & $17(60,7)$ & $0,015^{*}$ \\
Hari 7 & $0(0)$ & $28(100)$ & $0,000^{*}$ \\
Hari 10 & $16(59,3)$ & $28(100)$ & $0,025^{*}$ \\
Hari 14 & $27(100)$ & $28(100)$ & 1,000 \\
\hline
\end{tabular}

Ket: *: Chi-Square, $p<0,05, \mathrm{Cl} 95 \%$

\begin{tabular}{|c|c|c|c|}
\hline \multirow[t]{2}{*}{ Tinitus } & \multicolumn{2}{|c|}{ Kelompok } & \multirow[b]{2}{*}{$p$} \\
\hline & $\begin{array}{c}\text { Mikonasol } \\
n=27(\%)\end{array}$ & $\begin{array}{c}\text { Gentian violet } \\
n=28(\%)\end{array}$ & \\
\hline Hari 3 & $0(0)$ & $15(53,5)$ & $0,009^{*}$ \\
\hline Hari 7 & $2(7,40)$ & $28(100)$ & $0,005^{*}$ \\
\hline Hari 10 & $17(62,9)$ & $28(100)$ & $0,015^{*}$ \\
\hline Hari 14 & $27(100)$ & $28(100)$ & 0,492 \\
\hline
\end{tabular}

Ket: *: Chi-Square, $p<0,05, \mathrm{Cl} 95 \%$

\begin{tabular}{|lccc|}
\hline \multicolumn{4}{|c|}{$\begin{array}{l}\text { TABEL } 7 \\
\text { Perbedaan perbaikan tanda discad telinga } \\
\text { kedua kelompok }\end{array}$} \\
$\begin{array}{l}\text { Discad } \\
\text { telinga }\end{array}$ & $\begin{array}{c}\text { Mikonasol } \\
\boldsymbol{n = 2 7}(\%)\end{array}$ & $\begin{array}{c}\text { Gentian violet } \\
\boldsymbol{n = 2 8 ( \% )}\end{array}$ & $\boldsymbol{p}$ \\
\hline Hari 3 & $0(0)$ & $20(71,4)$ & $0,009^{*}$ \\
Hari 7 & $14(51,8)$ & $27(96,4)$ & $0,015^{*}$ \\
Hari 10 & $26(96,2)$ & $28(100)$ & 0,112 \\
Hari 14 & $27(100)$ & $28(100)$ & 1,000 \\
\hline
\end{tabular}

Ket: *: Chi-Square, $p<0,05, \mathrm{Cl} 95 \%$

Kelompok gentian violet lebih baik dalam hal perbaikan keluhan kurang dengar. Hari ke-14 tidak berbeda tentang keluhan kurang dengar pada kedua kelompok $(p=1.000)$. Terdapat perbedaan bermakna pada perbaikan keluhan kurang dengar kelompok GV dibanding kelompok mikonazol.

Tabel 6 hari ke-3, ke-7 dan ke-10 pasca terapi terdapat perbedaan bermakna pada perbaikan keluhan tinitus pada kedua kelompok $(p<0,05)$. Kelompok gentian violet lebih baik dalam hal perbaikan tinnitus. Hari ke-14 tidak berbeda terhadap perbaikan keluhan tinitus pada kedua kelompok $(p=0,492)$. Terdapat perbedaan bermakna pada perbaikan keluhan tinnitus kelompok GV dibanding kelompok mikonazol.

\begin{tabular}{|c|c|c|c|}
\hline \multicolumn{4}{|c|}{$\begin{array}{l}\text { Perbedaan perbaikan tanda edem CAE } \\
\text { kedua kelompok }\end{array}$} \\
\hline \multirow{2}{*}{$\begin{array}{l}\text { Edem } \\
\text { CAE }\end{array}$} & \multicolumn{2}{|c|}{ Kelompok } & \multirow[b]{2}{*}{$p$} \\
\hline & $\begin{array}{l}\text { Mikonasol } \\
n=27(\%)\end{array}$ & $\begin{array}{c}\text { Gentian violet } \\
n=28(\%)\end{array}$ & \\
\hline Hari 3 & $5(18,5)$ & $9(32,1)$ & 0,222 \\
\hline Hari 7 & $14(51,8)$ & $27(96,4)$ & $0,011^{*}$ \\
\hline Hari 10 & $24(88,8)$ & $28(100)$ & 0,103 \\
\hline Hari 14 & $26(96,3)$ & $28(100)$ & 0,112 \\
\hline
\end{tabular}

Ket: *: Chi-Square, $p<0,05, \mathrm{Cl} 95 \%$

\begin{tabular}{|lccc|}
\hline $\begin{array}{l}\text { TABEL } 9 \\
\text { Perbedaan perubahan tanda debris CAE } \\
\text { kedua kelompok }\end{array}$ \\
$\begin{array}{l}\text { Debris } \\
\text { CAE }\end{array}$ & $\begin{array}{c}\text { Melompok } \\
\boldsymbol{n = 2 7}(\%)\end{array}$ & $\begin{array}{c}\text { Gentian violet } \\
\boldsymbol{n = 2 8}(\%)\end{array}$ & $\boldsymbol{p}$ \\
\hline Hari 3 & $6(22,2)$ & $21(75,0)$ & $0,008^{*}$ \\
Hari 7 & $6(22,2)$ & $28(100)$ & $0,007^{*}$ \\
Hari 10 & $21(77,7)$ & $28(100)$ & $0,009^{*}$ \\
Hari 14 & $27(100)$ & $28(100)$ & 1,000 \\
\hline
\end{tabular}

Ket: *: Chi-Square, $p<0,05, \mathrm{Cl} 95 \%$

TABEL 10

Perubahan hasil pengecatan jamur CAE hari ke-7 \& ke-14

\begin{tabular}{lccc}
$\begin{array}{l}\text { Pengecatan } \\
\text { Jamur }\end{array}$ & \multicolumn{3}{c}{ Kelompok } \\
& $\begin{array}{c}\text { Mikonasol } \\
\text { Gent(\%) }\end{array}$ & $\begin{array}{c}\boldsymbol{n}=\mathbf{2 8}(\%) \\
\text { Hari ke-7 }\end{array}$ & \\
Hifa (-) & $11(40,7)$ & $15(53,5)$ & $0,422^{*}$ \\
Hifa (+) & $16(59,3)$ & $13(46,5)$ & \\
Hari ke-14 & & & \\
Hifa (-) & $24(88,8)$ & $25(89,2)$ & $1,000^{*}$ \\
Hifa (+) & $3(11,2)$ & $3(10,8)$ & \\
\hline
\end{tabular}

Ket: *: Chi-Square, $p<0,05, \mathrm{Cl} 95 \%$ 


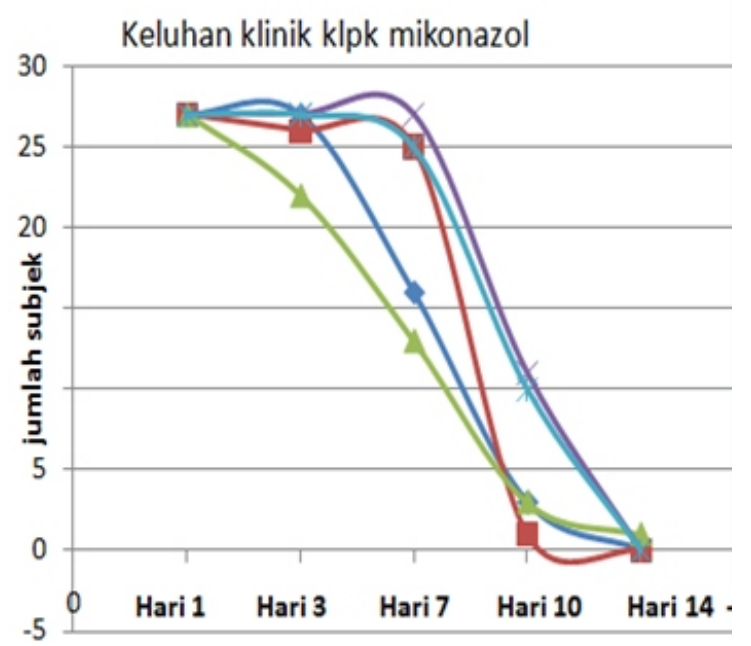

Gambar 1. Grafik perbandingan perbaikan keluhan kedua kelompok
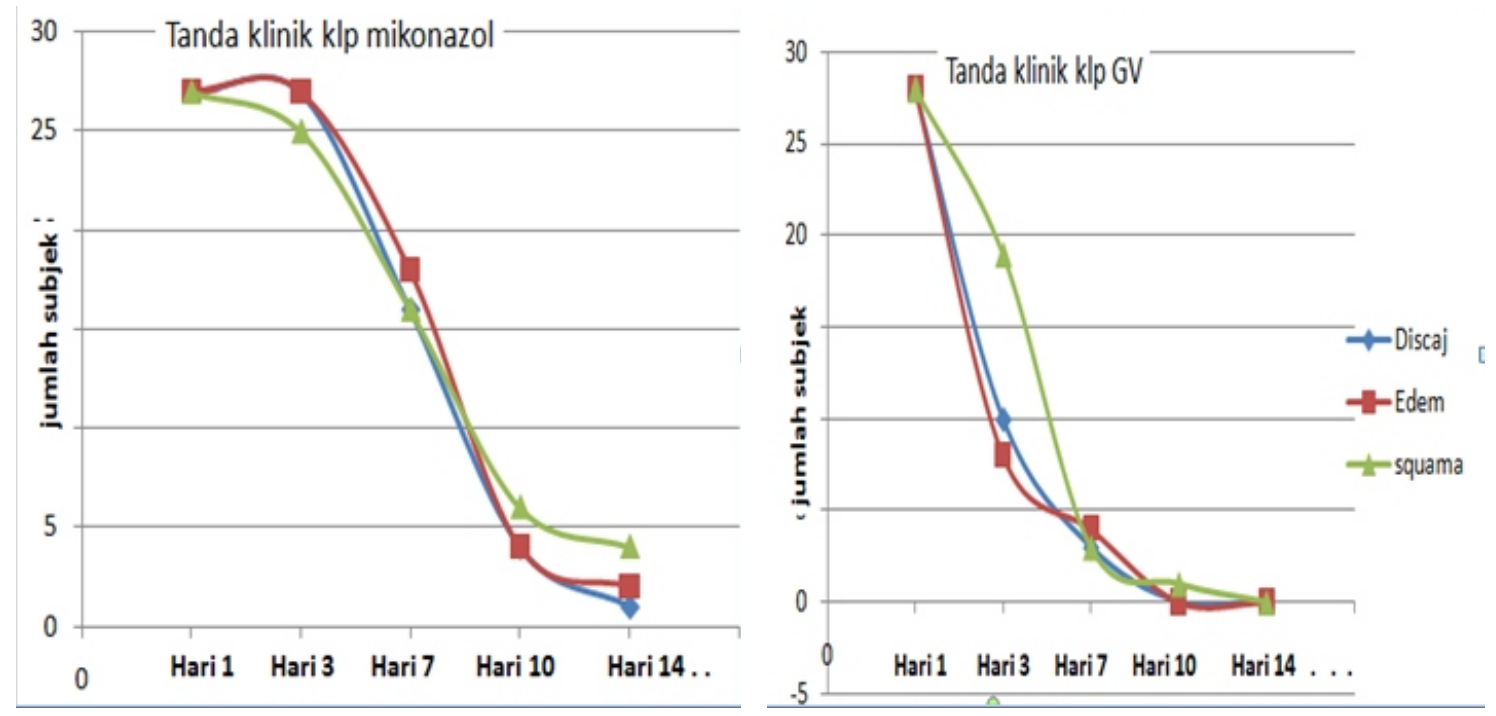

Gambar 2. Grafik perbedaan perbaikan tanda klinik kedua kelompok

Tabel 7 Menunjukkan pada hari ke-3 dan ke-7 terdapat perbedaan bermakna pada perbaikan tanda discad telinga pada kedua kelompok $(p<0,05)$. Kelompok gentian violet lebih baik dalam hal perubahan tanda discad telinga. Hari ke-10 dan ke-14 pasca terapi tampak tidak berbeda dalam hal perubahan tanda discaj telinga pada kedua kelompok $(p=0,112$ dan $p=1,000)$. Terdapat perbedaan bermakna pada perbaikan tanda klinik discad CAE kelompok GV dibanding kelompok mikonazol.

Tabel 8 Menunjukkan pada hari ke-7 terdapat perbedaan bermakna pada perbaikan tanda edem CAE pada kedua kelompok $(p<0,05)$. Kelompok gentian violet lebih baik dalam hal perubahan tanda CAE edem. Hari ke-3, ke-10 dan ke-14 pasca terapi tampak tidak berbeda pada kedua kelompok $(p>0,05)$. Terdapat perbedaan bermakna pada perbaikan tanda edem CAE kelompok GV dibanding kelompok mikonazol.
Tabel 9 Menunjukkan pada hari ke-3, ke-7 dan ke-10 pasca terapi terdapat perbedaan bermakna pada perbaikan tanda debris CAE pada kedua kelompok $(p<0,05)$. Kelompok GV lebih baik dalam hal perubahan tanda debris pada CAE. Hari ke-14, tampak tidak berbeda pada kedua kelompok $(p=1,000)$. Terdapat perbedaan bermakna pada perbaikan tanda debris CAE kelompok GV dibanding kelompok mikonazol.

Analisis multivariat pada semua keluhan dan tanda klinik, terdapat perbedaan bermakna pada perbaikan keluhan dan tanda klinik kelompok terapi GV $1 \%$ dibanding kelompok terapi mikonazol.

Tabel 10 Menunjukkan pada hari ke-7 $(p=0,422)$ dan ke-14 ( $p=1,000)$ tidak terdapat perbedaan bermakna antara kedua kelompok dalam hal perubahan hasil pengecatan jamur dari CAE. Kelompok GV tidak berbeda dibanding mikonazol krim pada perubahan hasil 
pengecatan jamur pasca terapi.

\section{PEMBAHASAN}

Otomikosis pada penelitian ini didapatkan pada rentang usia 10-69 tahun, terbanyak kelompok usia 41-50 tahun. Tang Ho menyebutkan dalam penelitiannya bahwa kasus otomikosis terbanyak pada usia dewasa muda (19-50 tahun) karena aktivitas mereka cukup banyak dan sering berada di luar ruangan. Aktivitas mereka yang tinggi memperbanyak produksi keringat sehingga kulit lembab. Kulit lembab ini mempermudah tumbuhnya koloni jamur. Koloni jamur akan makin mudah menginfeksi pada kulit yang lembab dan potensial terjadi mikrolesi. $^{6}$

Penelitian ini menunjukkan bahwa perbaikan keluhan dan tanda klinik pasca terapi larutan gentian violet $1 \%$ lebih baik dibanding terapi mikonazol krim $2 \%$.

Grafik 1 perbandingan perbaikan keluhan secara keseluruhan menunjukkan bahwa pada kelompok GV lebih baik dibanding kelompok mikonazol terhadap perbaikan keluhan gatal, discad telinga, nyeri, kurang pendengaran dan tinnitus. Grafik 2 perbandingan perbaikan tanda klinik secara keseluruhan menunjukkan bahwa kelompok GV lebih baik dibanding kelompok mikonazol terhadap tanda klinik discad CAE, edem dan debris CAE.

Perbedaan perbaikan keluhan dan tanda klinik ini terjadi karena gentian violet berupa larutan sehingga saat dioleskan akan merata ke seluruh permukaan CAE.

Larutan juga lebih mudah diserap secara osmosis oleh stratum korneum dari epidermis. Proses osmosis akan mudah terjadi pada media larutan dibanding krim. Penggunaan pelarut air akan makin mudah dibanding pelarut minyak. Larutan GV juga lebih mudah mengering sehingga tidak mengganggu konduksi suara di CAE. Keluhan kurang dengar akan segera membaik. Perbaikan pasca terapi pada GV akan lebih cepat, baik perbaikan keluhan maupun perbaikan tanda klinik. Mikonazol krim lebih lama terabsorsi dan menempel mengisi liang telinga sehingga dapat terjadi gangguan konduksi dalam mendengar. Mikonazol krim lebih kental komposisi nya sehingga proses absorsi di kulit akan lebih lambat. ${ }^{11}$

Palmer Komar (2008) menyebutkan bahwa antifungi berupa larutan lebih efektif dan mudah diaplikasikan dibanding antifungi bentuk krim sehingga akan mempercepat perbaikan keluhan dan tanda klinik otomikosis. $^{12}$

Menurut Innajara (2012) antifungal non spesifik spektrum luas (golongan alylamin) memberi hasil yang lebih baik dalam mengobati otomikosis. Gentian violet termasuk antifungal nonspesifik. Obat ini dapat sebagai bakterisid maupun fungisid sehingga dapat mengatasi superinfeksi berupa bakteri. Hal ini menyebabkan perbaikan keluhan dan tanda klinik lebih cepat terjadi. ${ }^{13}$
Larutan Gentian violet 1\% tidak lebih baik dibanding mikonazol krim 2\% dalam perubahan pengecatan jamur. Hal ini tidak sesuai studi oleh De Campo (2009) menjelaskan mekanisme GV dalam membunuh sel bakteri maupun jamur, yaitu: GV menghambat pembentukan squalen. Squalen ini akan membentuk lapisan lanosterol kemudian menjadi lapisan ergosterol yang melapisi dinding sel jamur. Lapisan ergosterol memperkuat dinding sel jamur. Jika lapisan ergosterol tidak terbentuk/ rusak sehingga dinding sel jamur terjadi lisis sitoplasma. Komponen mineral sitoplasma seperti $\mathrm{K}+$, fosfat, asam carbonat akan keluar dari intra sel. GV kemudian menuju inti sel jamur. Dalam inti sel GV menjadi zat antimetabolit yang bergabung dengan asam ribonukleat (RNA) sehingga menghambat mitosis sel jamur sehingga terjadilah kematian sel jamur. ${ }^{14}$

Obat yang mudah larut dalam air (larutan), merupakan bahan yang baik untuk difusi melalui stratum corneum seperti juga melalui epidermis. Sehingga obat tersebut lebih cepat bekerja. ${ }^{15}$

Larutan gentian violet tidak terbukti lebih baik dibanding mikonazol krim dalam hal perbaikan hasil pengecatan jamur, namun telah terbukti secara bermakna lebih baik dalam hal perbaikan keluhan maupun tanda klinik. Bentuk larutan mudah diaplikasikan secara merata ke CAE dan membran timpani, sehingga GV direkomendasikan sebagai terapi otomikosis yang efektif.

\section{Keterbatasan Penelitian}

Penelitian ini belum membahas faktor yang mempengaruhi kesembuhan otomikosis. Evaluasi pasca terapi dilakukan tidak setiap hari. Evaluasi perbaikan tanda klinik dilakukan peneliti sendiri tanpa disaksikan oleh minimal 2 pemeriksa lain sehingga memungkinkan bias pemeriksaan.

\section{SIMPULAN}

Terapi larutan Gentian violet $1 \%$ lebih efektif dibanding mikonazol krim 2\% terhadap perbaikan keluhan dan tanda klinik namun tidak menunjukkan perbedaan bermakna terhadap perubahan pengecatan jamur pada terapi otomikosis. Disarankan penelitian lebih lanjut mengenai pengamatan efektivitas terapi larutan gentian violet pada otomikosis dengan lama terapi yang lebih panjang dan menganalisis faktor yang mempengaruhi kesembuhannya.

\section{DAFTAR PUSTAKA}

1. Linstrom C, Lucente F. Infections of the external ear. In: Bailey, Byron J. Johnson, Jonas T. Newlands, Shawn D. Head \& Neck SurgeryOtolaryngology. $4^{\text {th }}$ Ed. New York. Lippincott Williams \&Wilkins. 2006. p:198-200. 
2. Ho M, Vrabec JT. Otomycosis: Clinical features and treatment implications. Journal Otolaryngol Head Neck Surg. 2009; p:787-791.

3. Ludman H. Fungal infection in external ear. The Journal of Otolaryngology-Head and neck Surgery. 2010;p. 264-83.

4. Djafar ZA, Kelainan telinga luar. Dalam: Soepardi EA, Iskandar N (Eds). Buku Ajar Ilmu Kesehatan Telinga Hidung Tenggorok Kepala \& Leher. Edisi ke-6. Jakarta: Balai Penerbit FK UI. 2007;49-62.

5. Segun T. Chronic otitis externa with otomycosis. The Journal of Otolaryngology-Head and neck Surgery. 2012;p: 114-34

6. Ho T, Jeffrey TV, Donald Y, Newton JC. Fungal external otitis: Clinical features and treatment. The Journal of OtolaryngologyHead and Neck Surgery. 2010;p:787-791.

7. Hueso G, Gil ES. Presumed diagnosis: Otomycosis, a study of 451 patients. Acta Otorinolaringol Eps. 2009;p: 231-40.

8. Dixon D, Bernard H. Treating swimmer's ear and its complication. British Medical Journal. 2009. p:405-409.

9. Kumar A. Fungal spectrum in Otomycosis patients with immunocompromized and clinical findings. JK Sciences. 2009; p:115-26.
10. Zarei A. Mycological studies in 15 cases of otomycosis treated with acetic acid solution 2\%. Pakistan of Medical Sciences. 2009.p:134-40.

11. Komar P. Clinical study of effects of arkataila solution compared to clotrimasol solution. In: Ayurveda Dipika Journal Cakrapanidatta. 2008; p:144-9.

12. Ridge $M$, Aboul U. Management challenge in otomycosis in Callabar, South Africa. African Medical Assocition. 2010; p.231-237

13. Innajara R, Moawad D. Broadspectrum antifungal agents in otomycosis, J Laryngol Otol. 2012;p.867-79.

14. De Campo R, Moreno SN. The metabolism and mode of action of gentian violet. In: WHO, Drug Metabolism Revision. 2009; p:161-78.

15. Mugliston T, O'Donoghue G. Topical treatment in Otomycosis: A continuing problem. in: Alford BR eds. Head and Neck Surgery-Department of Otolaryngology. Baylor College of Medicine. Houston, Texas. 2010; p:99,327-33. 